\title{
Application of the governance disruptions framework to German agricultural soil policy
}

\author{
Bartosz Bartkowski ${ }^{1}$, Stephan Bartke ${ }^{1}$, Nina Hagemann ${ }^{2}$, Bernd Hansjürgens ${ }^{1}$, and \\ Christoph Schröter-Schlaack ${ }^{1}$ \\ ${ }^{1}$ Department of Economics, Helmholtz Centre for Environmental Research (UFZ), Leipzig, Germany \\ ${ }^{2}$ International Institute Zittau, Technische Universität Dresden, Zittau, Germany \\ Correspondence: Bartosz Bartkowski (bartosz.bartkowski@ufz.de)
}

Received: 15 February 2021 - Discussion started: 3 March 2021

Revised: 29 June 2021 - Accepted: 8 July 2021 - Published: 4 August 2021

\begin{abstract}
Governance of natural resources is inherently complex and requires navigating trade-offs at multiple dimensions. In this paper, we present and operationalize the "governance disruptions framework" (GDF) as a tool for holistic analysis of natural resource governance systems. For each of the four dimensions of the framework (target adequacy, object adequacy, instrument adequacy, and behavioural adequacy), we formulate guiding questions to be used when applying the framework to particular governance systems. We then demonstrate the use of GDF by applying it to the core of German agricultural soil policy. We show that for each framework dimension, the governance system exhibits deficits, particularly with respect to object adequacy and instrument adequacy. Furthermore, we use the GDF-based analysis to highlight research gaps. We find that stakeholder analyses are a central gap across GDF dimensions.
\end{abstract}

\section{Introduction}

Governance of natural resources is an inherently complex challenge. It involves crafting, sustaining and transforming institutions (formal and informal rules) to navigate conflicts and trade-offs with respect to property rights (Bartkowski et al., 2018; Schlager and Ostrom, 1992), societal targets (Pradhan et al., 2017) and preferences of various stakeholder groups (Cavender-Bares et al., 2015). A broad, holistic view on governance arrangements is required in order to identify ways to make such arrangements more effective in protecting critical natural resources.

A critical natural resource that is only slowly gaining attention and prominence is soil, especially agricultural soil (Keesstra et al., 2016; Vogel et al., 2018). Despite being affected by a multitude of policies, land and soil degradation is an ongoing problem globally (IPBES, 2018a) and in Europe (IPBES, 2018b; Panagos et al., 2018). In the European Union (EU), the proposal for a "soil framework directive" was rejected in 2014 due to claimed sufficient cover of soil protec- tion in existing legal frameworks of the EU and its member states (Glæsner et al., 2014).

The question of whether soils are sufficiently protected by current policies in the EU has been addressed from multiple perspectives, often focusing primarily on the identification of relevant policies (e.g. Juerges and Hansjürgens, 2018; Ronchi et al., 2019; Stankovics et al., 2018; Turpin et al., 2017). Less frequently, authors tried to link these policies to soil threats, soil functions (Glæsner et al., 2014), multifunctionality (Vrebos et al., 2017) or resilience (Juerges et al., 2018). These analyses collectively suggest that soil protection through the EU and member states remains deficient. The focus of this literature is, however, on the relationship between a broad set of policy instruments and a narrow subset of soil-related policy objectives. However, a broader view of the multiple dimensions of agricultural soil governance is missing. This broader view, aiming to overcome the existing deficits in soil governance, can result from investigating basic assumptions and questions related to key dimensions constituting the current governance arrangements. 


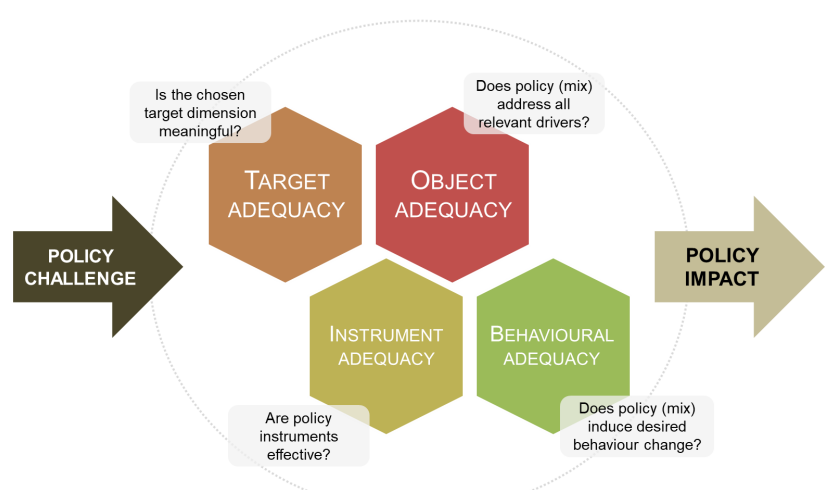

Figure 1. Governance disruptions framework (GDF) (modified after Schröter-Schlaack and Hansjürgens, 2019, Fig. 48.2)

In this article, we seek to analyse agricultural soil governance in a systematic manner: first, we present the "governance disruptions framework" (GDF), a holistic conceptual framework for analysis of natural resource governance, originally proposed by Schröter-Schlaack and Hansjürgens (2019). We operationalize the framework by formulating questions for each of its dimensions. Second, we apply the framework in an exploratory way to offer a broad perspective on the shortcomings of current governance of agricultural soils in Germany. We focus on the formulation and implementation of national and EU policies with relevance to agricultural soil protection. Using the previously formulated questions for each GDF dimension, we draw from available scientific literature to provide responses to these questions. Our overall aim is to identify gaps or, framed more positively, windows of opportunity in the German agricultural soil governance system and the interactions between these gaps or opportunities. Furthermore, we suggest areas particularly requiring further research based on our analysis.

\section{Conceptual framework: governance disruptions}

To properly analyse and navigate complex governance systems and the trade-offs they imply, there is a need for conceptual perspectives that can reflect this complexity. In this article, we adopt the GDF, which was originally proposed with the aim to overcome the shortcomings of simplistic governance models (Schröter-Schlaack and Hansjürgens, 2019).

The framework (Fig. 1) consists of four interrelated elements that address different dimensions of a potential policy success or failure: target adequacy, object adequacy, instrument adequacy and behavioural adequacy. Together, they determine the impact of a governance arrangement or policy mix with respect to an underlying societal challenge, such as soil degradation. Disruptions in each dimension can lead to policy failure; interactions between the dimensions can have compound effects. Therefore, the benefit is in looking at all four of them together and exploring the interlinkage between them (e.g. disruptions in one dimension that affect another dimension or related disruptions across dimensions). In order to operationalize the framework, we formulate guiding questions for each of the dimensions, which we later apply to the context of agricultural soil governance in Germany.

\subsection{Target adequacy - are targets properly defined and meaningful?}

The first element of the disruptions framework is related to the identification of adequate target dimensions (or dimension) to form the basis for policy intervention. For instance, EU agricultural targets conflict with each other (e.g. farmers' income support, affordable food, environmental protection) (Pe'er et al., 2019) and are imprecise (e.g. referring to the ambiguous concept of "good agricultural practice" as a baseline for the allocation of compliance costs between the farmer and society) (Möckel, 2015a). Furthermore, often they target particular management practices (action-based approaches), rather than targeting changes in environmental objectives more directly (result-based approaches) (Burton and Schwarz, 2013), as increasingly emphasized in the context of the European Green Deal (EC, 2020a). Given the heterogeneity of local environmental conditions, such contradicting and/or imprecise targets can result in ineffective or inefficient policies. Furthermore, understanding the relationships (synergies and trade-offs) between different target dimensions (e.g. different sustainability goals associated with different soil functions or ecosystem services) is crucial for a policy to be successful (Schaafsma and Bartkowski, 2020). Tangible, clearly defined and measurable target dimensions are required for policy interventions - it needs to be clear what the target status of, for example, a multifunctional landscape is, which requires a good understanding of both the biophysical potential of ecosystems (Seppelt et al., 2013) and the relevant societal preferences as well as the identity and interests of those affected (Cavender-Bares et al., 2015). Failure to identify the target dimensions and properly understand the relationships among them, e.g. in agricultural policies, may make policy interventions ineffective at best, potentially aggravating soil degradation at worst. In other words, coherence is required already at the level of policy targets (Nilsson et al., 2012).

We propose the following questions to guide the analysis of the target adequacy of a policy mix:

Q1 What are the specific environmental objectives to be achieved? How can objectives be clearly linked to concrete indicators that allow for operationalization and monitoring?

Q2 Which spatial and temporal scales are relevant for each objective? 
Q3 What interactions between individual objectives or indicators are known? Are they taken into account when setting objectives?

Q4 What are relevant stakeholder groups and their preferences towards the natural resource in question, and are there trade-offs between the preferences of the stakeholder groups?

\subsection{Object adequacy - are relevant (direct and indirect) drivers addressed?}

The second element of the GDF relates to the identification of the causes (drivers) of environmental degradation, i.e. the objects of policy intervention. Effective policy responses for more sustainable natural resource and ecosystem management and an effective navigation of trade-offs require identifying and addressing all relevant direct and indirect drivers of environmental degradation. Policy interventions targeting only a specific driver or being restricted to a specific domain or sector (e.g. agricultural practices) may be ineffective if activities contributing to environmental degradation in other domains (e.g. companies' behaviour in the value chain or food consumption patterns) are not addressed as well. Domains include both human activities and natural processes (e.g. climate change and its effects on other environmental objectives). In the case of anthropogenic drivers, interests of stakeholder groups and power relationships become relevant (Berbés-Blázquez et al., 2016). The necessity of identifying indirect drivers of environmental change has also been emphasized by the recent IPBES (2019) report on biodiversity and ecosystem services. Furthermore, it is crucial to take into account interactions between drivers (e.g. climate change increasing soil erosion) and between the policy interventions addressing them (e.g. subsidies for bioenergy production to fight climate change contradicting other environmental policies). Lastly, it is important to note that the role of particular drivers is usually not certain, especially in a particular local context.

The following questions may guide analyses of the object adequacy of a policy mix:

Q1 Which (direct and indirect) drivers are known and what are the associated uncertainties?

Q2 How do the effects of the drivers vary across spatial and temporal scales?

Q3 Which drivers are particularly relevant and/or have particularly strong effects (and thus may require prioritization)?

Q4 What are known interactions among drivers?

Q5 Which stakeholder groups have interests associated with particular drivers (qui bono?)?

\subsection{Instrument adequacy - are instruments properly chosen and designed?}

The third element of the GDF is related to the choice and design of policy instruments. It focuses on individual instruments as well as their joint role within an instrument mix (Ring and Schröter-Schlaack, 2015). Common instrumentspecific evaluation criteria are effectiveness and efficiency (Hanley et al., 1999), ${ }^{1}$ but other criteria such as the capacity to support resilience and legitimacy have been discussed (e.g. Juerges et al., 2018). The usual classification of policy instruments distinguishes regulatory command-and-control instruments (e.g. spatial planning, mandatory management requirements), incentive-based instruments (e.g. taxes, tradable permits, subsidies) and "soft" informational instruments (e.g. nudges, labelling, public procurement) (Bemelmans-Videc et al., 1998), though in practice hybrid instruments are often found (Blackstock et al., 2021). Instrument choice and design is an art: each instrument class has relative advantages and disadvantages that need to be analysed in a contextspecific way and especially in relation to the societal targets and drivers of environmental degradation they are supposed to address. Furthermore, interactions between various instruments are particularly relevant for assessing each instrument's effectiveness and efficiency (Blackstock et al., 2021; Braathen, 2007; Schader et al., 2014). The choice of the instrument mix influences the distribution of benefits among stakeholder groups, which can be used as a guide to select appropriate instruments (Pannell, 2008) and is related to the issues discussed with respect to object adequacy (qui bono?). Also, it is important to keep in mind that policy instruments never operate in isolation. Rather, they are embedded in an existing institutional and cultural context that may influence their effectiveness and efficiency, especially with respect to transaction costs (Bolognesi and Nahrath, 2020).

We propose the following questions to guide analyses of instrument adequacy:

Q1 Which instruments address the environmental objective? Are there interdependencies among instruments?

Q2 How is the correspondence between the instruments and known drivers?

Q3 Are the individual instruments effective and efficient?

Q4 Is the mix of instruments coherent? Are there overlaps or gaps?

\footnotetext{
${ }^{1}$ There exist many subcriteria for both effectiveness and efficiency, including environmental effectiveness and additionality as dimensions of effectiveness and cost-effectiveness and dynamic efficiency as dimensions of efficiency.
} 


\subsection{Behavioural adequacy - (how) will instruments trigger desired behavioural changes?}

The fourth element of the GDF relates to the implicit or explicit assumptions about human behaviour embodied in particular instruments: does people's behaviour follow the predicted patterns; i.e. can the policy intervention effectively trigger desired behaviour change? Ultimately, this has crucial consequences for the effectiveness and efficiency of policy instruments. Sometimes, policy addressees do not respond to an otherwise well-designed intervention, because the underlying assumptions regarding their behaviour are incorrect. This is a particular challenge for conservation and management of natural ecosystems, where a broad range of motivations (instrumental, social, intrinsic) for action is involved (Bartkowski and Bartke, 2018; Dessart et al., 2019). The heterogeneous distribution of motivations in the target population and among relevant stakeholder groups should be taken into account when designing policy interventions (Braito et al., 2020). Also, legitimacy and acceptance of the policy intervention by the addressees is an important issue here (Vainio et al., 2021), which points to interactions between behavioural adequacy and object adequacy (qui bono?). These considerations are strongly instrument-dependent - for instance, incentive-based and soft instruments can be highly sensitive to behavioural factors such as social influence, while regulatory instruments are less so. On the other hand, even for the latter, compliance levels may vary depending on the interactions between institutional context (e.g. monitoring) and behavioural factors. More generally, asymmetric information between policy makers and land users is a challenge in which behavioural, social and institutional factors play a large role. In many cases, combinations of instruments may help to address the behavioural shortcomings of individual ones - e.g. the combination of monetary incentives with the provision of information necessary to realize the incentivized behaviour change (e.g. Blackstock et al., 2021).

The following questions may be used to guide the analysis of behavioural adequacy:

Q1 How well do the underlying behavioural assumptions of the instruments reflect actual behaviour of the target population?

Q2 How well do the instruments reflect the heterogeneity of behavioural characteristics of the target population?

Q3 Are there behavioural complementarities or contradictions between the instruments?

\section{Case study: agricultural soil governance in Germany}

In what follows, we apply the GDF, as introduced above, to the governance of agricultural soils in Germany. In order to leverage the breadth of the framework and demonstrate its potential to illuminate governance and policy analysis, we will address the GDF-based guiding questions (summarized in Table 1 below) and point out knowledge gaps. We focus on policy documents and instruments in Germany that $e x$ plicitly address agricultural soils. We therefore abstract from the many more instruments that have a rather implicit or indirect yet non-negligible relevance for soil governance (e.g. Nitrate Directive, Water Framework Directive or spatial planning laws) in order to keep our analysis focused. Germany is a particularly interesting example, because it is one of the few countries with explicit legislation for soil protection (Juerges and Hansjürgens, 2018; Ronchi et al., 2019). The German Federal Soil Protection Act (Bundes-Bodenschutzgesetz, denoted BBodSchG) came into force in 1999; it defines a framework for soil protection in Germany, with a particular focus on contaminated soils and their restoration. Section 17 is explicitly dealing with agricultural soil management. Within the European Common Agricultural Policy (CAP), the main instruments addressing soil management explicitly are the "good agricultural and environmental condition" (GAEC) guidelines (first CAP pillar) and the agrienvironment and climate measures (AECMs) (second pillar). Both instruments have been implemented in German law through ordinances. In addition, other relevant policies are referred to, especially in the context of target adequacy.

\subsection{Approach and methods}

Table 1 summarizes the questions for each GDF dimension that will be used to guide the analysis of agricultural soil governance in Germany. Our analysis is based on the scientific literature, which we contrast with relevant policy documents where appropriate. In cases where the questions cannot be answered on the basis of literature and document analysis, we formulate research or knowledge gaps.

\subsection{Results and discussion}

In this section, we discuss each dimension of the governance disruptions framework (GDF) by addressing the questions from Table 1.

\subsubsection{Target adequacy}

Q1 - What are the specific environmental objectives? How can these be linked to concrete indicators?

As Möckel (2015b) points out, there are essentially two policy documents that formulate explicit, legally binding targets regarding agricultural soil management in Germany: the Federal Soil Protection Act (BBodSchG) and the "good agricultural and environmental condition" (GAEC) guidelines within CAP direct payments cross-compliance rules. ${ }^{2}$ The

\footnotetext{
${ }^{2}$ BBodSchG can be found at https://www.gesetze-im-internet. de/bbodschg/, and GAEC can be found at https://eur-lex.europa.eu/
} 
Table 1. Research questions for the explorative application of the governance disruptions framework to agricultural soil governance in Germany.

\begin{tabular}{ll}
\hline Dimension & GDF questions \\
\hline Target adequacy & What are the specific environmental objectives? How can these be linked to concrete indicators? \\
& Which spatial and temporal scales are relevant for each objective? \\
& What interactions between individual objectives or indicators are known? Are they taken into account? \\
& What are relevant stakeholder groups and their preferences towards agricultural soils, and are there \\
trade-offs between the preferences of the stakeholder groups?
\end{tabular}

BBodSchG stresses the need to "sustain and restore soil functions" with a strong focus on soil contamination, which reflects the historic implementation purpose of the act to prevent harm from contaminated land (particularly for humans). The soil functions invoked in the BBodSchG include "natural functions", "archive" for natural and cultural history, and "use functions", which are only limitedly related to the soil function concepts common in scientific literature (e.g. Vogel et al., 2018; Zwetsloot et al., 2021). Both the BBodSchG and soil-relevant GAEC guidelines emphasize erosion protection and the requirement to sustain the site-specific soil organic carbon (SOC) content. Furthermore, the BBodSchG also addresses avoiding soil compaction and sustaining and improving biological activity in soils. Thus, while the BBodSchG seems to combine soil functions and soil threats in its formulation of targets, the GAEC guidelines address only a limited set of threats. No specific indicators are formulated in the analysed policy documents. Similar findings were reported by Marx and Jacobs (2020) in their analysis of German policy documents related specifically to soil compaction.

At the EU level, the Farm to Fork Strategy (F2F) and the Biodiversity Strategy as parts of the European Green Deal are also relevant recent strategic documents that include references to soil protection (Montanarella and Panagos, 2021). ${ }^{3}$

legal-content/en/ALL/?uri=CELEX:32013R1306 (Annex II) (both last access: 2 November 2020).

${ }^{3}$ As mentioned by Montanarella and Panagos (2021), further soil-relevant strategies are scheduled for 2021, e.g. the Zero Pol-
The Biodiversity Strategy explicitly mentions "limiting soil sealing", bringing back "at least $10 \%$ of agricultural area under high-diversity landscape features" to, among others, limit soil erosion, and preventing soil degradation for its ecosystem services ("soil fertility, nutrient cycling and climate regulation") (EC, 2020b). At the even higher international level, the Sustainable Development Goals (SDGs) have been used as a set of policy targets - however, as pointed out by Keesstra et al. (2016), while soils are relevant for multiple SDGs, they are rarely explicitly mentioned (one exception being soil organic carbon stocks used as one of the indicators for SDG15). These gaps may be a reflection of data (non-)availability as an important constraint of environmental policy, though the recently launched EU Soil Observatory has the potential to improve the situation significantly (Montanarella and Panagos, 2021). In this sense, soil policy can be considered an art of making decisions and creating instruments in the absence of perfect knowledge and in a way that allows for adaption to new knowledge.

\section{Q2 - Which spatial and temporal scales are relevant for each objective?}

Given the low specificity of the soil-related objectives identified in the above-mentioned policy documents, scale considerations can only limitedly be assessed. Some work has

lution Action Plan for Air, Water and Soil and an update of the Soil Thematic Strategy. 
been done on the temporal and spatial dimensions and mismatches associated with different soil-based ecosystem services (mentioned in the EU Biodiversity Strategy), which can be linked to soil functions (BBodSchG) (Bartkowski et al., 2020). However, the consequences of these mismatches for governance have not yet been spelled out and constitute a research gap. It seems undisputed that the short- to mid-term AECMs are not adequately in line with natural soil processes (Juerges et al., 2018; Vogel et al., 2018).

\section{Q3 - What interactions between individual objectives are} known? Are they taken into account?

Given the general formulation of most targets related to agricultural soil governance in Germany, it is difficult to assess trade-offs between them. The exception is the BBodSchG's reference to soil functions, which are known to involve tradeoffs (Bartkowski et al., 2020; Paul and Helming, 2019), especially when considered in specific environmental and management contexts (Schröder et al., 2020). For instance, organic fertilization is desirable in terms of nutrient cycling, but it may be detrimental to water quality because of the mismatch between $\mathrm{N} / \mathrm{P}$ ratios in organic fertilizer and the demands of most crops (Schröder et al., 2020), as exemplified by the high spatial correlation of livestock production (and thus local availability of organic fertilizer) and nitrate pollution in north-western Germany. However, these trade-offs are not explicitly acknowledged in the BBodSchG. With respect to the GAEC, it has been repeatedly noted that the superordinate $\mathrm{CAP}$ is an incoherent combination of targets and instruments, where contradictory environmental and productionoriented targets and instruments exist alongside each other (Pe'er et al., 2019).

\section{Q4 - What are relevant stakeholder groups and their preferences towards the natural resource in question, and are there trade-offs between the preferences of the stakeholder groups?}

A tentative stakeholder analysis for German agricultural soil governance has been conducted by Jürges (2016). Because of the centrality of soils to agricultural production and environmental protection, the identified spectrum of actors is fairly broad, ranging from environmental and agricultural research institutes through farmers' associations to government ministries and agencies. We are not aware of any comprehensive analysis of their role in relevant policy processes (see also Techen et al., 2020). Also, given the general paucity of preference analyses in the context of agricultural soils in Germany (Bartkowski et al., 2020), possible trade-offs and, more generally, the relevance of preference heterogeneity are unknown. Stakeholder analyses constitute a major gap in soil governance research in Germany.

\subsubsection{Object adequacy}

Q1 - Which (direct and indirect) drivers are known and what are the associated uncertainties?

Techen and Helming (2017) provide a comprehensive list of drivers of soil management, categorizing them into three classes: socioeconomic, biophysical and technological. As socioeconomic drivers, they identify consumer demand, factor costs, policies and farm(er)s' attributes. The last two will be addressed in the discussions of the next two dimensions, so we exclude them from the discussion of object adequacy. As biophysical drivers, Techen and Helming (2017) list soil degradation threats, land availability, climate change and resource scarcity. Among technological drivers, they find research, biomass technology, information and communications technology (ICT) and robotics, and other technology. For the purposes of the present analysis, the last class can be summarized as "research and technology", except for "biomass technology", which we consider as predominantly another (industrial) demand factor, adding to the conventional demand for food and feed that Techen and Helming (2017) subsume as "consumer demand". Soil (degradation) threats have been used to identify sectors contributing to soil degradation, including, next to agriculture, urbanization (land take), industry (contamination) and nature protection (with mostly co-benefits for sustainable soil management) (Glæsner et al., 2014). Land availability is of course a driver of intensification and thus can be related to soil threats. Relatedly, ownership status of agricultural land (specifically, tenure) has frequently been hypothesized to negatively influence the sustainability of soil management (e.g. Soule et al., 2000); however, recent empirical insights from Europe have questioned this hypothesis (Daedlow et al., 2018; Leonhardt et al., 2019).

Looking at the soil-relevant governance arrangements discussed here, it is striking that rules mostly address the production side, ignoring the influence of other parts of the food chain from field to consumers. The F2F strategy may change this with its explicit inclusion of consumption and the overall food chain, but its impact strongly depends on how it will interact with the CAP.

Q2 - How do the effects of the drivers vary across spatial and temporal scales?

As indicated above, there are discordances between natural soil processes taking place at different time and spatial scales and the potential of governance to provide sensitive steering measures. We are not aware of holistic, systematic analyses of spatial variations between drivers of agricultural soil degradation in Germany. Some information is implicit in comparing scenario development processes with different spatial scales - e.g. Shared Socioeconomic Pathways for European agriculture and food systems (Mitter et al., 2020) emphasize different drivers of change than global or national 
scenarios. However, while we are aware of ongoing scenario development with a specific focus on Germany, which would help in this context, there are no existing results to draw upon. With regard to temporal scales, foresight (Techen and Helming, 2017) and scenario analyses (Mitter et al., 2020) can provide expert- or model-based hints at possible variation with respect to different drivers. However, since (the pace of) technological developments and value changes are inherently difficult to predict, there are limits to such analyses.

\section{Q3 - Which drivers are particularly relevant and/or have} particularly strong effects (and thus may require prioritization)?

Prioritization for policy purposes, including prioritization of drivers of soil degradation, is an inherently normative exercise, and different prioritization results will be arrived at depending on the chosen yardstick. Drivers of soil degradation and related pressures are well-known and obvious not only to experts. Such drivers are climate change, economic growth or lifestyle preferences often leading to similar pressures (e.g. Hagemann et al., 2019), which makes prioritization difficult. From the point of view of soil research, some prioritization was undertaken by Techen et al. (2020), who identified "cross-cutting research challenges" related to various drivers of soil degradation and to different soil threats and functions. However, these research challenges are not necessarily correlated with the policy relevance and effect strength of drivers. Here, again, dedicated research efforts are required.

\section{Q4 - Are there known interactions among drivers?}

The most obvious source of interactions between drivers of soil degradation in Germany is climate change - however, its direct and indirect (via adaptation strategies) effects are still only insufficiently understood. With respect to soils and agriculture, it is increasingly obvious that climate change will lead to more and longer drought periods in central Europe (Samaniego et al., 2018), making adaptive changes to soil management necessary, e.g. shifts in crop rotations (Peichl et al., 2019) and increased reliance on irrigation (Riediger et al., 2016). Different climate adaptation options differ in their effects on soil functions (Hamidov et al., 2018). Climatechange-induced weather extremes could also interact with mechanical pressures to aggravate water and wind erosion (Borrelli et al., 2020, 2017). Rising industrial demand for biomass, associated with the bioeconomy (Bruckner et al., 2019), and shifts in consumer demand in response to increasing sustainability challenges can also be expected to interact with the other drivers of soil degradation.
Q5 - Which stakeholder groups have interests associated with particular drivers (qui bono?)?

As already mentioned in the discussion of target adequacy, the identification and analysis of stakeholders in the "soil governance field" (Jürges, 2016) is a major research gap; accordingly, we are not aware of any literature looking at questions of the relationship between vested interests and soil degradation drivers.

\subsubsection{Instrument adequacy}

Q1 - Which instruments address the environmental objective? Are there interdependencies?

The spectrum of policy instruments that influence agricultural soil management is quite broad, as demonstrated by the comprehensive EU-level compilation in the Ecologic Institute inventory (Frelih-Larsen et al., 2016; see also Ronchi et al., 2019). However, when it comes to policy instruments that address soils explicitly and that have a direct influence on agricultural soil-relevant decision-making and behaviour of relevant actors, member-state-level GAEC specifications and AECMs appear to be the most important; in the following, we will focus on these two (as noted above, the BBodSchG is a policy document of mainly declaratory nature). Regarding interactions between instruments, it should be noted here that given the overall structure of the CAP, GAEC-based measures should be viewed as defining the mandatory baseline for agricultural soil management, while AECMs attempt at incentivizing voluntary actions that go beyond this baseline. In Table 2, we list all arable-land AECMs across German federal states (CAP funding period 2014-2020) that can be directly linked to soil protection via the soil pressures as stated in Techen and Helming (2017). The following information on AECMs is based on Deutsche Vernetzungsstelle Ländlicher Raum (2015) and complementary searches on responsible agencies' websites. In most federal states, there are also AECMs for extensive management of permanent grassland that affect soil functions - however, these have explicit biodiversity-oriented goals and are therefore excluded here.

The most basic result of the information collated in table 2 is that two soil-related AECMs - diverse crop rotations and cover crops $^{4}-$ are most common, while other AECMs addressing soil management are only present in a small subset of federal states each. Furthermore, there are no result-based or otherwise site-specific soil-related AECMs - in fact, this is a general challenge in the EU as a whole, where result-based schemes are so far restricted to biodi-

\footnotetext{
${ }^{4}$ Note that cover crops are also one of the Ecological Focus Areas (EFAs) options for fulfilling the so-called greening requirements for CAP direct payments; in fact, they are pretty often chosen (Zinngrebe et al., 2017). Given that greening is usually justified in terms of biodiversity conservation, however, we restrict ourselves to pointing this out.
} 
Table 2. Soil-related AECMs in German federal states. Notes: BB - Brandenburg/Berlin, BW - Baden-Württemberg, BY - Bavaria, HE - Hesse, MV - Mecklenburg-Vorpommern, NI - Lower Saxony/Bremen, NW - North Rhine-Westphalia, RP - Rhineland-Palatinate, SH Schleswig-Holstein/Hamburg, SL - Saarland, SN - Saxony, ST - Saxony-Anhalt, TH - Thuringia.

\begin{tabular}{|c|c|c|c|c|c|c|c|c|c|c|c|c|c|}
\hline AECMs in federal states & $\mathrm{BB}$ & $\mathrm{BW}$ & BY & $\mathrm{HE}$ & MV & $\mathrm{NI}$ & NW & $\mathrm{RP}$ & $\mathrm{SH}$ & SL & $\mathrm{SN}$ & ST & $\mathrm{TH}$ \\
\hline Diverse crop rotation & $\mathrm{x}$ & $\mathrm{x}$ & $\mathrm{x}$ & $\mathrm{x}$ & $\mathrm{x}$ & $\mathrm{x}$ & $\mathrm{x}$ & $\mathrm{x}$ & $\mathrm{x}$ & & & $\mathrm{x}$ & $\mathrm{x}$ \\
\hline Cover crops & $\mathrm{x}$ & $\mathrm{x}$ & $\mathrm{x}$ & & & $\mathrm{x}$ & $\mathrm{x}$ & $\mathrm{x}$ & $\mathrm{x}$ & $\mathrm{x}$ & $\mathrm{x}$ & $\mathrm{x}$ & \\
\hline Stubble over winter & & & & & & & & & & & $\mathrm{x}$ & & \\
\hline Reduced or no till & & $\mathrm{x}$ & $\mathrm{x}$ & & & $\mathrm{x}$ & & & & & $\mathrm{x}$ & & \\
\hline Erosion protection strips & & & $\mathrm{x}$ & $\mathrm{x}$ & & $\mathrm{x}$ & & & & & & & $\mathrm{x}$ \\
\hline Erosion protection hedges & & & & & & $\mathrm{x}$ & & & & & & & \\
\hline No herbicides & & $\mathrm{x}$ & & & & & & & & & & & \\
\hline Precise fertilization & & $\mathrm{x}$ & & & & $\mathrm{x}$ & & & & & & & \\
\hline Precision farming & & $\mathrm{x}$ & & & & & & & & & & & \\
\hline
\end{tabular}

versity protection (Bartkowski et al., 2021). ${ }^{5}$ However, this may reflect the challenges in terms of monitoring "results" such as soil functions (Jeffery and Verheijen, 2020; Vogel et al., 2019), whereas innovative, e.g. model-based, payment schemes might be a promising alternative (Bartkowski, 2021; Bartkowski et al., 2021).

\section{Q2 - How is the correspondence between the instruments and known drivers?}

In Table 3 we link the identified AECMs to soil pressures and soil functions. To do this, we use the results of a systematic review on agricultural land management and soil properties (Chapman et al., 2018), whose gaps we complement by other reviews: on the effects of diversified crop rotations on soil properties (Bai et al., 2018), on the effects of herbicides on soil organisms (Gunstone et al., 2021; Rose et al., 2016) and on the effects of tillage intensity of soil organic carbon (Haddaway et al., 2017). We combine the information derived from the reviews with a mapping of soil properties and soil functions (Vogel et al., 2019). We focus on those four soil functions identified by Vogel et al. $(2019,2018)$ that exhibit public good characteristics; i.e. we ignore biomass production or fertility. The four considered soil functions are nutrient cycling (NC in Table 4), carbon storage (CS), water storage and filtration (WSF), and biological diversity (BD).

As shown in Table 3, the effects of most soil-related AECMs on soil functions are either zero or unknown (including the widespread cover crops), exceptions being reduced tillage and hedge planting, where the literature suggests positive effects across soil functions. This is in line with Vrebos et al. (2017), who showed on the EU level that soil functions are addressed by policies in a rather incoherent and nonsystematic manner.

\footnotetext{
${ }^{5}$ The only result-based agri-environmental payment scheme focusing on soils that we are aware of is the pilot "Klimaschutz durch Humusaufbau" programme in the Swiss canton Basel-Landschaft, which started in 2019.
}

Looking at the soil pressures associated with the AECMs, most measures address impacts related to (narrow) crop rotations and mechanical pressures, while spatial patterns and inputs into soil are seldom addressed. Furthermore, given our focus on CAP-related instruments, other, broader drivers of soil degradation are not addressed. There is a general lack of dedicated instruments addressing the impacts on agricultural soils from industrial and consumer demand, apart from organic food labels. Also, climate change as a driver of soil degradation but also soil's role in mitigating climate change has not been addressed in a systematic manner by means of policy instruments, despite initiatives such as 4p1000 (Rumpel et al., 2020) or private soil carbon certification schemes (Wiesmeier et al., 2020). Furthermore, land availability remains an issue, even though options for novel instruments related to land take (Marquard et al., 2020) and rearrangement and/or reallocation (Bartkowski et al., 2018; Binder, 2019) have been addressed in the scientific literature.

A remarkable example of policy instruments ignoring relevant drivers despite available knowledge and data is discussed by Siebert (2020), who looked at the erosion cadastres used in German federal states to implement GAEC rules. She shows that in most cases not all relevant factors affecting soil erosion risk have been included in the definition of risk zones with management restrictions; for instance, rain erodibility was ignored in the Saxon erosion cadastre, thus leading to an overly optimistic assessment of the extent of areas affected by erosion risk. Moreover, using the case study of bioenergy-relevant crops, Siebert (2020) argues that the common erosion cadastre approach ignores the importance of specific crops in determining erosion risk (see also Borrelli and Panagos, 2020).

\section{Q3 - Are the individual instruments effective and efficient?}

There is a general paucity of studies looking at the effectiveness of policy instruments in improving the condition of soils, especially going beyond analyses of soil erosion and 
Table 3. German soil-related AECMs and their relation to soil pressures and soil functions. Note that soil pressures are based on Techen and Helming (2017). Soil functions: NC - nutrient cycling, CS - carbon storage, WSF - water storage and filtration, BD - biodiversity; “+” positive effect on property strongly associated with soil function according to Vogel et al. (2019), "(+)" - positive effect on properties with minor association to soil function, "0" - no effect on properties associated with soil function, "-_ - negative effect on properties associated with soil function, "?" - effect not known.

\begin{tabular}{llcccc}
\hline AECMs & Soil pressures addressed & \multicolumn{3}{c}{ Soil functions addressed } \\
\cline { 3 - 6 } & & NC & CS & WSF & BD \\
\hline Diverse crop rotation & Crop rotations & $(+)$ & + & $(+)$ & $(+)$ \\
Cover crops & Crop rotations, mechanical pressures & $?$ & 0 & - & $?$ \\
Stubble over winter & Crop rotations, mechanical pressures & $?$ & 0 & 0 & $(+)$ \\
Reduced or no till & Mechanical pressures & $?$ & 0 & $(+)$ & $(+)$ \\
Erosion protection strips & Mechanical pressures, spatial patterns & $?$ & $?$ & $?$ & $?$ \\
Erosion protection hedges & Spatial patterns & $(+)$ & + & + & $(+)$ \\
No herbicides & Inputs into soil & $?$ & $?$ & $?$ & $(+)$ \\
Precise fertilization & Inputs into soil & $?$ & $?$ & $?$ & $?$ \\
Precision farming & Inputs into soil & $?$ & $?$ & $?$ & $?$ \\
\hline
\end{tabular}

towards the effects on soil multifunctionality. Among the few available pieces of evidence, modelling studies suggest that the introduction of GAEC rules as part of CAP crosscompliance has reduced soil erosion rates (Borrelli and Panagos, 2020), while there is also tentative evidence suggesting that crop diversification may actually have the opposite effect (Gocht et al., 2017). In general, however, there is an urgent need for more empirical and modelling studies of the effectiveness, as well as investigations into the efficiency (e.g. cost-effectiveness) of soil-related policy instruments on soil functions.

\section{Q4 - Is the mix of instruments coherent? Are there overlaps or gaps?}

Lack of coherence of the soil-related policy mix on the European level has been bemoaned in the literature (Ronchi et al., 2019), which is related to a lack of an overarching EU policy framework explicitly addressing soils (Glæsner et al., 2014). Table 2 shows clearly the strongly varying number and extent of soil-targeted AECMs across German federal states, just as they vary across member states of the EU.

Given that all relevant policy instruments are related to the CAP, they are rather well aligned - for instance, AECMs are required to only incentivize practices that are not mandatory under GAEC or (in the case of cover crops) already used to fulfil greening requirements. Overall, there are few distinct policy instruments related to soils, so one cannot observe any apparent contradictions or incoherences, unless looking beyond soil-targeting policies and including those with indirect effects (e.g. bioenergy subsidies; see Siebert, 2020). Even incentives for seemingly contradictory practices (e.g. in many contexts, it is currently not feasible to farm without herbicide application while at the same time applying no-till practices; Zikeli and Gruber, 2017) can be interpreted as reflecting the heterogeneity of soils and business models that need to be addressed by policies. The problem, therefore, does not seem to be (primarily) coherence but rather ambition and effectiveness.

\subsubsection{Behavioural adequacy}

Q1 - How well do the underlying behavioural assumptions of the instruments reflect actual behaviour of the target population?

As discussed above, the main policies addressing agricultural soil management in Germany are GAEC and AECMs, whereby the former secure a minimal baseline of soil protection, while the latter address soil protection and multifunctionality (somewhat) more broadly and comprehensively. Relying on mandatory instruments, such as GAEC, implies the (tacit) assumption that agents will behave in accordance to them. Meanwhile, empirical evidence suggests that reality may not be as simple and that, in the absence of effective monitoring, there are various reasons for farmers to violate mandatory requirements (see Gaymard et al., 2020). Furthermore, the minimal baseline provided by GAEC and also, less concretely, the BBodSchG means that, ultimately, soil protection is mainly based on voluntary, monetary incentives. It is well known that economic considerations are the strongest determinants of farmers' management decisions, but it has also repeatedly been shown that other motivational factors also play a role (Bartkowski and Bartke, 2018). For instance, Bartkowski and Bartke (2018) show that, depending on the specific context, factors such as general pro-environmental attitudes or problem perception can play an important role in soil-related decisions.

A common indicator of success (conditional on behavioural adequacy) of voluntary incentive-based instruments is their uptake. This is strongly dependent on payment levels but also on goodness of fit in relation to the usual prac- 
tices and operation procedures as well as available equipment of a farm (and, on the other side of the equation, on public budget availability). Also, it has been shown in other contexts that transparent communication of AECM goals, administrative rules and responsibilities and perceived administrative effort associated with participation are important for uptake (Brouwer et al., 2015; Mack et al., 2020, 2019). Accordingly, uptake rates vary across AECM types. Overall, irrespective of the specific type of AECM (soil- and non-soil-related), uptake levels between $5 \%$ and $20 \%$ of arable land area are common (uptake in grasslands is usually higher) (Grajewski, 2016). Moreover, there is a strong tendency to adoption of the "easiest" measures, which limits the effectiveness of AECMs (Bartkowski and Bartke, 2018; see also Zinngrebe et al., 2017). However, uptake data alone are a highly imperfect indicator of behavioural adequacy, because of potentially confounding factors (especially budget constraints faced by administrative bodies). There is a need for more dedicated analyses of behavioural factors that determine AECM uptake.

\section{Q2 - How well do the instruments reflect the}

heterogeneity of behavioural characteristics of the target population?

Braito et al. (2020) show for Austria that one can distinguish different groups of farmers whose basic motivations for sustainable soil management differ, ranging from purely economic motives (based on AECM payment rates) to intrinsic motivations that may only require information and training rather than monetary incentives. Neither AECMs nor GAEC seem to reflect the behavioural heterogeneity of farmers - they offer standardized incentives with limited room for adaptation to biophysical and behavioural characteristics.

\section{Q3 - Are there behavioural complementarities or contradictions between the instruments?}

We are not aware of any research into the interplay of mandatory and incentive-based instruments with regard to farmers' environmentally relevant behaviour. In the UK context, it was argued by Blackstock et al. (2021) that availability of advisory services can be a precondition for AECM uptake (see also Ingram and Mills, 2019). However, given a lack of similar analyses in Germany, as well as the underrepresentation of sustainable soil management in the very heterogeneous German system of agricultural extension services, this cannot be verified in the context of our case study.

\section{Lessons learnt}

\subsection{The case study}

This article used the GDF to provide an exploratory analysis of the German agricultural soil governance. For all four dimensions of the framework - target adequacy, object adequacy, instrument adequacy and behavioural adequacy - we found deficits, most of which can be linked to the generally underappreciated role of sustainable soil management in German and EU agri-environmental policy. In fact, soil-related policies are fragmented, underdeveloped and not comprehensive; e.g. they do not explicitly and directly address all soil functions and the interactions between them. This lack of coherence and depth starts already at the level of political targets and propagates throughout the framework's four dimensions. We would like to underline the following deficits that appear particularly concerning.

When looking at explicitly soil-dedicated policies, three major drivers of soil degradation (potential) - namely climate change (both in terms of soil's mitigation potential and the interaction between sustainable soil management and climate change adaptation), the bioeconomy as a new source of demand for biomass and the food chain beyond production - remain largely unaddressed. However, this may change due to the introduction of the European Green Deal (Montanarella and Panagos, 2021).

Relatedly, the multifunctionality of soils seems largely unaddressed; targets found both in strategic documents and, implicitly, in policy instruments do not reflect well the multiple functions and ecosystem services provided by soils nor the interactions (especially trade-offs) among them.

The effectiveness of dedicated agricultural soil policy instruments is questionable, which partly reflects their rather rudimentary design (e.g. lack of more site-specific and/or result-based instruments addressing the heterogeneity of soils).

The heterogeneity of the farmer population and the complex determinants of their behaviour are not well reflected in existing policy documents, likely because of simplistic understanding of farmers' motivation by policy makers (see Brown et al., 2021).

Against this background, two major practical consequences for soil policy appear particularly salient: first, effective soil policy requires clearly and realistically formulated targets that take into account the current understanding of underlying mechanisms and availability of data for monitoring the success of policy interventions. Second, much knowledge is available about behavioural factors that affect the effectiveness of environmental policies, including soil-related management (Bartkowski and Bartke, 2018). However, the (implicit) assumptions reflected in conventional policy design are rather simplistic (Brown et al., 2021). This calls for more consideration of behavioural factors in soil policy design. In addition to these two issues - and given that soil 
policy is covered at various governance levels (from EU to federal states and further down) while being implemented "on the ground" by farmers - communication (of and about soil policy targets, sustainable management practices, legal competencies, administrative rules, etc.) across governance levels and among stakeholders is crucial for successful soil protection.

On the positive side, the combination of a mandatory minimum standard (GAEC) with incentives for the adoption of "additional" soil protecting management practices (AECMs) seems to be a good starting point for further developing the production side of soil governance in Germany and the EU.

While trying to provide tentative answers to the questions formulated in Sect. 2, we identified the following research gaps, where evidence is missing and where there is a need for dedicated research.

- There is an urgent need for more research attention on the actors or stakeholders involved in and affected by soil governance, their preferences, vested interested, their association with drivers of soil degradation, etc.

- The temporal and spatial dimensions in the context of targets, drivers, preferences and instruments, including temporal and spatial mismatches, require more research.

- Studies into possible prioritization of different drivers of soil degradation would be helpful for more effective and rapid policy formulation.

- There is a general paucity of research into effectiveness of policy instruments as well as, relatedly, the behaviour of relevant actors (particularly farmers) in the specific context of agricultural soil management.

\subsection{The GDF applied to agricultural soil policy assessment}

Overall, we found the GDF to be useful in generating a broad overview about the challenges of agricultural soil governance in Germany. However, we also identified a trade-off between the (realistic) level of detail and the breadth and number of issues addressed - being so comprehensive, the disruptions framework requires the synthesis of very many pieces of evidence, which can be challenging within limits of time and other resources. In our case study, we restricted ourselves to policy documents and instruments that address agricultural soils explicitly, knowing that one could include many more policies that have a more implicit or indirect yet non-negligible relevance in the analysed governance context. Moreover, there is the challenge of navigating between different levels of analysis - while policy targets are often formulated at national and supranational levels, specific policy instruments are often designed and implemented at national or even, as in the case of Germany's agri-environmental policy, regional levels. One may say that in this respect the GDF reflects the challenges of the policy arena that we have applied it to, where communication across levels is essential (see above). The GDF has proven quite useful in facilitating the structured identification of research gaps relevant to a comprehensive analysis of natural resource governance. Following this exploratory application, the GDF can now be tailored to more specific aims and contexts, in order to illuminate particular aspects of the natural resource governance. This may include pragmatic simplification to facilitate GDF's use as an analysis tool for policy makers.

Data availability. The following publicly available legal texts have been used in this paper: BBodSchG (https://www.gesetze-im-internet.de/bbodschg/) and GAEC (https://eur-lex.europa.eu/legal-content/en/ALL/?uri=CELEX: 32013R1306) (both last access: 2 November 2020).

Author contributions. All authors conceptualized the paper. BB prepared the article with contributions from all co-authors.

Competing interests. The authors declare that they have no conflict of interest.

Disclaimer. Publisher's note: Copernicus Publications remains neutral with regard to jurisdictional claims in published maps and institutional affiliations.

Acknowledgements. We would like to thank the three anonymous referees for their constructive and helpful comments and Nele Lienhoop, Sylvia Bittner, Marieke Baaken and Ulrich Weller for consultation and support. This work was funded by the German Federal Ministry of Education and Research (BMBF) in the framework of the funding measure "Soil as a Sustainable Resource for the Bioeconomy - BonaRes", project "BonaRes (Module B): BonaRes Centre for Soil Research, subproject A" (grant 031B0511A).

Financial support. This research has been supported by the Bundesministerium für Bildung und Forschung (grant no. 031B0511A).

The article processing charges for this open-access publication were covered by the Helmholtz Centre for Environmental Research - UFZ.

Review statement. This paper was edited by Giacomo Certini and reviewed by three anonymous referees. 


\section{References}

Bai, Z., Caspari, T., Gonzalez, M. R., Batjes, N. H., Mäder, P., Bünemann, E. K., de Goede, R., Brussaard, L., Xu, M., Ferreira, C. S. S., Reintam, E., Fan, H., Mihelič, R., Glavan, M., and Tóth, Z.: Effects of agricultural management practices on soil quality: A review of long-term experiments for Europe and China, Agric. Ecosyst. Environ., 265, 1-7, https://doi.org/10.1016/j.agee.2018.05.028, 2018.

Bartkowski, B.: Don't throw efficiency out with the bathwater: A reply to Jeffery and Verheijen (2020), Environ. Sci. Policy, 122, 72-74, https://doi.org/10.1016/j.envsci.2021.04.011, 2021.

Bartkowski, B. and Bartke, S.: Leverage Points for Governing Agricultural Soils: A Review of Empirical Studies of European Farmers' Decision-Making, Sustainability, 10, 3179, https://doi.org/10.3390/su10093179, 2018.

Bartkowski, B., Hansjürgens, B., Möckel, S., and Bartke, S.: Institutional Economics of Agricultural Soil Ecosystem Services, Sustainability, 10, 2447, https://doi.org/10.3390/su10072447, 2018.

Bartkowski, B., Bartke, S., Helming, K., Paul, C., Techen, A.-K., and Hansjürgens, B.: Potential of the economic valuation of soilbased ecosystem services to inform sustainable soil management and policy, PeerJ, 8, e8749, https://doi.org/10.7717/peerj.8749, 2020.

Bartkowski, B., Droste, N., Ließ, M., Sidemo-Holm, W., Weller, U., and Brady, M. V.: Payments by modelled results: A novel design for agri-environmental schemes, Land Use Policy, 102, 105230, https://doi.org/10.1016/j.landusepol.2020.105230, 2021.

Bemelmans-Videc, M.-L., Rist, R. C., and Vedung, E. (Eds.): Carrots, sticks \& sermons: policy instruments and their evaluation, Transaction Publishers, New Brunswick, N.J., U.S.A, 280 pp., 1998.

Berbés-Blázquez, M., González, J. A., and Pascual, U.: Towards an ecosystem services approach that addresses social power relations, Curr. Opin. Environ. Sustain., 19, 134-143, https://doi.org/10.1016/j.cosust.2016.02.003, 2016.

Binder, S.: Flurbereinigungsplanung und Ökosystemschutz als Rechts- und Governance-Problem, Metropolis-Verlag, Marburg, 426 pp., 2019.

Blackstock, K. L., Novo, P., Byg, A., Creaney, R., Juarez Bourke, A., Maxwell, J. L., Tindale, S. J., and Waylen, K. A.: Policy instruments for environmental public goods: Interdependencies and hybridity, Land Use Policy, 107, 104709, https://doi.org/10.1016/j.landusepol.2020.104709, 2021.

Bolognesi, T. and Nahrath, S.: Environmental Governance Dynamics: Some Micro Foundations of Macro Failures, Ecol. Econ., 170, 106555, https://doi.org/10.1016/j.ecolecon.2019.106555, 2020.

Borrelli, P. and Panagos, P.: An indicator to reflect the mitigating effect of Common Agricultural Policy on soil erosion, Land Use Policy, 92, 104467, https://doi.org/10.1016/j.landusepol.2020.104467, 2020.

Borrelli, P., Lugato, E., Montanarella, L., and Panagos, P.: A New Assessment of Soil Loss Due to Wind Erosion in European Agricultural Soils Using a Quantitative Spatially Distributed Modelling Approach, Land Degrad. Dev., 28, 335-344, https://doi.org/10.1002/ldr.2588, 2017.

Borrelli, P., Robinson, D. A., Panagos, P., Lugato, E., Yang, J. E., Alewell, C., Wuepper, D., Montanarella, L., and Ballabio, C.:
Land use and climate change impacts on global soil erosion by water (2015-2070), P. Natl. Acad. Sci. USA, 117, 21994-22001, https://doi.org/10.1073/pnas.2001403117, 2020.

Braathen, N. A.: Instrument Mixes for Environmental Policy: How Many Stones Should be Used to Kill a Bird?, Int. Rev. Environ. Resour. Econ., 1, 185-235, https://doi.org/10.1561/101.00000005, 2007.

Braito, M., Leonhardt, H., Penker, M., Schauppenlehner-Kloyber, E., Thaler, G., and Flint, C. G.: The plurality of farmers' views on soil management calls for a policy mix, Land Use Policy, 99, 104876, https://doi.org/10.1016/j.landusepol.2020.104876, 2020.

Brouwer, R., Lienhoop, N., and Oosterhuis, F.: Incentivizing afforestation agreements: Institutional-economic conditions and motivational drivers, J. For. Econ., 21, 205-222, https://doi.org/10.1016/j.jfe.2015.09.003, 2015.

Brown, C., Kovács, E., Herzon, I., Villamayor-Tomas, S., Albizua, A., Galanaki, A., Grammatikopoulou, I., McCracken, D., Olsson, J. A., and Zinngrebe, Y.: Simplistic understandings of farmer motivations could undermine the environmental potential of the Common Agricultural Policy, Land Use Policy, 101, 105136, https://doi.org/10.1016/j.landusepol.2020.105136, 2021.

Bruckner, M., Häyhä, T., Giljum, S., Maus, V., Fischer, G., Tramberend, S., and Börner, J.: Quantifying the global cropland footprint of the European Union's non-food bioeconomy, Environ. Res. Lett., 14, 045011, https://doi.org/10.1088/17489326/ab07f5, 2019.

Burton, R. J. F. and Schwarz, G.: Result-oriented agrienvironmental schemes in Europe and their potential for promoting behavioural change, Land Use Policy, 30, 628-641, https://doi.org/10.1016/j.landusepol.2012.05.002, 2013.

Cavender-Bares, J., Polasky, S., King, E., and Balvanera, P.: A sustainability framework for assessing trade-offs in ecosystem services, Ecol. Soc., 20, https://doi.org/10.5751/ES-06917-200117, 2015.

Chapman, P. J., Eze, S., de Bell, S., Barlow-Duncan, F., Firbank, L., Helgason, T., Holden, J., Kay, P., Brown, C. D., White, P. C. L., Little, R., Reed, M., and Ziv, G.: Agricultural Land Management for Public Goods Delivery: iCASP Evidence Review on Soil Health, Yorkshire Integrated Catchment Solutions Programme (iCASP), 2018.

Daedlow, K., Lemke, N., and Helming, K.: Arable Land Tenancy and Soil Quality in Germany: Contesting Theory with Empirics, Sustainability, 10, 2880, https://doi.org/10.3390/su10082880, 2018.

Dessart, F. J., Barreiro-Hurlé, J., and van Bavel, R.: Behavioural factors affecting the adoption of sustainable farming practices: a policy-oriented review, Eur. Rev. Agric. Econ., 46, 417-471, https://doi.org/10.1093/erae/jbz019, 2019.

Deutsche Vernetzungsstelle Ländliche Räume: ELER in Deutschland: Übersicht über die Nationale Rahmenregelung und die Programme der Länder. Programmübersicht 2014-2020, Deutsche Vernetzungsstelle Ländliche Räume; Bundesanstalt für Landwirtschaft und Ernährung, Bonn, 2015.

EC: A Farm to Fork Strategy for a fair, healthy and environmentallyfriendly food system [COM(2020) 381], European Commission, Brussels, 2020a. 
EC: EU Biodiversity Strategy for 2030: Bringing nature back to our lives [COM(2020) 380], European Commission, Brussels, 2020b.

Frelih-Larsen, A., Bowyer, C., Albrecht, S., Keenleyside, C., Kemper, M., Nanni, S., Naumann, S., Mottershead, D., Landgrebe, R., Andersen, E., Banfi, P., Bell, S., Brémere, I., Cools, J., Herbert, S., Iles, A., Kampa, E., Kettunen, M., Lukacova, Z., Moreira, G., Kiresiewa, Z., Rouillard, J., Okx, J., Pantzar, M., Paquel, K., Pederson, R., Peepson, A., Pelsy, F., Petrovic, D., Psaila, E., Šarapatka, B., Sobocka, J., Stan, A.-C., Tarpey, J., and Vidaurre, R.: Updated inventory and assessment of soil protection policy instruments in EU Member States, Ecologic, Berlin, 2016.

Gaymard, S., Goujon, B., and Lefebvre, M.: Adherence to Environmental Regulation in the European Union Common Agricultural Policy: Social Representations and Conditionality among French Farmers, J. Agric. Food Inf., 21, 104-125, https://doi.org/10.1080/10496505.2020.1772078, 2020.

Glæsner, N., Helming, K., and de Vries, W.: Do Current European Policies Prevent Soil Threats and Support Soil Functions?, Sustainability, 6, 9538-9563, https://doi.org/10.3390/su6129538, 2014.

Gocht, A., Ciaian, P., Bielza, M., Terres, J.-M., Röder, N., Himics, M., and Salputra, G.: EU-wide economic and environmental impacts of CAP greening with high spatial and farm-type detail, J. Agric. Econ., 68, 651-681, https://doi.org/10.1111/14779552.12217, 2017.

Grajewski, R.: Vier ländliche Entwicklungsprogramme im Vergleich: PFEIL Niedersachsen-Bremen, LPLR Schleswig-Holstein, NRW-Programm Ländlicher Raum und EPLR Hessen: Finanzen - Fördermaßnahmen - Prioritäten - Investitionstypen - Zielgruppen - Implementation, Thünen-Institut, Braunschweig, 2016.

Gunstone, T., Cornelisse, T., Klein, K., Dubey, A., and Donley, N.: Pesticides and Soil Invertebrates: A Hazard Assessment, Front. Environ. Sci., 9, https://doi.org/10.3389/fenvs.2021.643847, 2021.

Haddaway, N. R., Hedlund, K., Jackson, L. E., Kätterer, T., Lugato, E., Thomsen, I. K., Jørgensen, H. B., and Isberg, P.-E.: How does tillage intensity affect soil organic carbon? A systematic review, Environ. Evid., 6, 30, https://doi.org/10.1186/s13750-017-01089, 2017.

Hagemann, N., Álvaro-Fuentes, J., Siebielec, G., Castañeda, C., Maring, L., Blauw, M., Bartke, S., Dietze, V., Arrúe, J. L., Playán, E., Herrero, J., and Plaza-Bonilla, D.: Providing support in relation to the implementation of the EU Soil Thematic Strategy. Drivers and transboundary impacts of soil degradation, DG Environment, Brussels, 2019.

Hamidov, A., Helming, K., Bellocchi, G., Bojar, W., Dalgaard, T., Ghaley, B. B., Hoffmann, C., Holman, I., Holzkämper, A., Krzeminska, D., Kværnø, S. H., Lehtonen, H., Niedrist, G., Øуgarden, L., Reidsma, P., Roggero, P. P., Rusu, T., Santos, C., Seddaiu, G., Skarbøvik, E., Ventrella, D., Żarski, J., and Schönhart, M.: Impacts of climate change adaptation options on soil functions: A review of European case-studies, Land Degrad. Dev., 29, 2378-2389, https://doi.org/10.1002/ldr.3006, 2018.

Hanley, N., Whitby, M., and Simpson, I.: Assessing the success of agri-environmental policy in the UK, Land Use Policy, 16, 6780, https://doi.org/10.1016/S0264-8377(98)00041-6, 1999.

Ingram, J. and Mills, J.: Are advisory services "fit for purpose" to support sustainable soil management? An assess- ment of advice in Europe, Soil Use Manag., 35, 21-31, https://doi.org/10.1111/sum.12452, 2019.

IPBES: The assessment report on land degradation and restoration, IPBES Secretariat, Bonn, 2018a.

IPBES: The regional assessment report on biodiversity and ecosystem services for Europe and Central Asia, IPBES Secretariat, Bonn, 2018b.

IPBES: Summary for policymakers of the global assessment report on biodiversity and ecosystem services of the Intergovernmental Science-Policy Platform on Biodiversity and Ecosystem Service, IPBES Secretariat, Bonn, 2019.

Jeffery, S. and Verheijen, F. G. A.: A new soil health policy paradigm: Pay for practice not performance!, Environ. Sci. Policy, 112, 371-373, https://doi.org/10.1016/j.envsci.2020.07.006, 2020.

Juerges, N. and Hansjürgens, B.: Soil governance in the transition towards a sustainable bioeconomy - A review, J. Clean. Prod., 170, 1628-1639, https://doi.org/10.1016/j.jclepro.2016.10.143, 2018.

Juerges, N., Hagemann, N., and Bartke, S.: A tool to analyse instruments for soil governance: the REELframework, J. Environ. Policy Plan., 20, 617-631, https://doi.org/10.1080/1523908X.2018.1474731, 2018.

Jürges, N.: Wahrnehmungen und Funktionen in der Transformation zur Bioökonomie - Eine Akteursanalyse im Politikfeld "Boden", Helmholtz-Zentrum für Umweltforschung, Leipzig, 2016.

Keesstra, S. D., Bouma, J., Wallinga, J., Tittonell, P., Smith, P., Cerdà, A., Montanarella, L., Quinton, J. N., Pachepsky, Y., van der Putten, W. H., Bardgett, R. D., Moolenaar, S., Mol, G., Jansen, B., and Fresco, L. O.: The significance of soils and soil science towards realization of the United Nations Sustainable Development Goals, SOIL, 2, 111-128, https://doi.org/10.5194/soil-2-111-2016, 2016.

Leonhardt, H., Penker, M., and Salhofer, K.: Do farmers care about rented land? A multi-method study on land tenure and soil conservation, Land Use Policy, 82, 228-239, https://doi.org/10.1016/j.landusepol.2018.12.006, 2019.

Mack, G., Kohler, A., Heitkämper, K., and El-Benni, N.: Determinants of the perceived administrative transaction costs caused by the uptake of an agri-environmental program, J. Environ. Plan. Manag., 62, 1802-1819, https://doi.org/10.1080/09640568.2018.1515311, 2019.

Mack, G., Ritzel, C., and Jan, P.: Determinants for the Implementation of Action-, Result- and Multi-Actor-Oriented AgriEnvironment Schemes in Switzerland, Ecol. Econ., 176, 106715, https://doi.org/10.1016/j.ecolecon.2020.106715, 2020.

Marquard, E., Bartke, S., Gifreu i Font, J., Humer, A., Jonkman, A., Jürgenson, E., Marot, N., Poelmans, L., Repe, B., Rybski, R., Schröter-Schlaack, C., Sobocká, J., Tophøj Sørensen, M., Vejchodská, E., Yiannakou, A., and Bovet, J.: Land Consumption and Land Take: Enhancing Conceptual Clarity for Evaluating Spatial Governance in the EU Context, Sustainability, 12, 8269, https://doi.org/10.3390/su12198269, 2020.

Marx, K. and Jacobs, A.: SOILAssist-Teilprojekt "Akzeptanz und Implementierung": Analyse behördlicher Handlungsempfehlungen zur Vermeidung von Bodenverdichtung auf Ackerböden, Thünen Working Paper, https://doi.org/10.3220/WP1604915142000, 2020. 
Mitter, H., Techen, A.-K., Sinabell, F., Helming, K., Schmid, E., Bodirsky, B. L., Holman, I., Kok, K., Lehtonen, H., Leip, A., Le Mouël, C., Mathijs, E., Mehdi, B., Mittenzwei, K., Mora, O., Øistad, K., Øygarden, L., Priess, J. A., Reidsma, P., Schaldach, R., and Schönhart, M.: Shared Socioeconomic Pathways for European agriculture and food systems: The Eur-Agri-SSPs, Glob. Environ. Change, 65, 102159, https://doi.org/10.1016/j.gloenvcha.2020.102159, 2020.

Möckel, S.: "Best available techniques" as a mandatory basic standard for more sustainable agricultural land use in Europe?, Land Use Policy, 47, 342-351, https://doi.org/10.1016/j.landusepol.2015.04.021, 2015a.

Möckel, S.: Politische und rechtliche Ziele zum vorsorgenden Schutz der Böden in Deutschland, Nat. Landsch., 90, 497-502, 2015b.

Montanarella, L. and Panagos, P.: The relevance of sustainable soil management within the European Green Deal, Land Use Policy, 100, 104950, https://doi.org/10.1016/j.landusepol.2020.104950, 2021.

Nilsson, M., Zamparutti, T., Petersen, J. E., Nykvist, B., Rudberg, P., and McGuinn, J.: Understanding Policy Coherence: Analytical Framework and Examples of Sector-Environment Policy Interactions in the EU, Environ. Policy Gov., 22, 395-423, https://doi.org/10.1002/eet.1589, 2012.

Panagos, P., Standardi, G., Borrelli, P., Lugato, E., Montanarella, L., and Bosello, F.: Cost of agricultural productivity loss due to soil erosion in the European Union: From direct cost evaluation approaches to the use of macroeconomic models, Land Degrad. Dev., 29, 471-484, https://doi.org/10.1002/ldr.2879, 2018.

Pannell, D. J.: Public Benefits, Private Benefits, and Policy Mechanism Choice for Land-Use Change for Environmental Benefits, Land Econ., 84, 225-240, https://doi.org/10.3368/le.84.2.225, 2008.

Paul, C. and Helming, K.: Handbook of Soil-Related Impact Assessment, BonaRes Centre, 2019.

Pe'er, G., Zinngrebe, Y., Moreira, F., Sirami, C., Schindler, S., Müller, R., Bontzorlos, V., Clough, D., Bezák, P., Bonn, A., Hansjürgens, B., Lomba, A., Möckel, S., Passoni, G., Schleyer, C., Schmidt, J., and Lakner, S.: A greener path for the EU Common Agricultural Policy, Science, 365, 449-451, https://doi.org/10.1126/science.aax3146, 2019.

Peichl, M., Thober, S., Samaniego, L., Hansjürgens, B., and Marx, A.: Climate impacts on long-term silage maize yield in Germany, Sci. Rep., 9, 7674, https://doi.org/10.1038/s41598-019-44126-1, 2019.

Pradhan, P., Costa, L., Rybski, D., Lucht, W., and Kropp, J. P.: A Systematic Study of Sustainable Development Goal (SDG) Interactions, Earths Future, 5, 1169-1179, https://doi.org/10.1002/2017EF000632, 2017.

Riediger, J., Breckling, B., Svoboda, N., and Schröder, W.: Modelling regional variability of irrigation requirements due to climate change in Northern Germany, Sci. Total Environ., 541, 329_ 340, https://doi.org/10.1016/j.scitotenv.2015.09.043, 2016.

Ring, I. and Schröter-Schlaack, C.: Policy mixes for biodiversity conservation and ecosystem service management, in: Ecosystem services - Concept, methods and case studies, edited by: Grunewald, K. and Bastian, O., Springer, Berlin Heidelberg, 146-155, 2015.
Ronchi, S., Salata, S., Arcidiacono, A., Piroli, E., and Montanarella, L.: Policy instruments for soil protection among the EU member states: A comparative analysis, Land Use Policy, 82, 763-780, https://doi.org/10.1016/j.landusepol.2019.01.017, 2019.

Rose, M. T., Cavagnaro, T. R., Scanlan, C. A., Rose, T. J., Vancov, T., Kimber, S., Kennedy, I. R., Kookana, R. S., and Van Zwieten, L.: Impact of Herbicides on Soil Biology and Function, Adv. Agron., 136, 133-220, https://doi.org/10.1016/bs.agron.2015.11.005, 2016.

Rumpel, C., Amiraslani, F., Chenu, C., Garcia Cardenas, M., Kaonga, M., Koutika, L.-S., Ladha, J., Madari, B., Shirato, Y., Smith, P., Soudi, B., Soussana, J.-F., Whitehead, D., and Wollenberg, E.: The 4p1000 initiative: Opportunities, limitations and challenges for implementing soil organic carbon sequestration as a sustainable development strategy, Ambio, 49, 350-360, https://doi.org/10.1007/s13280-019-01165-2, 2020.

Samaniego, L., Thober, S., Kumar, R., Wanders, N., Rakovec, O., Pan, M., Zink, M., Sheffield, J., Wood, E. F., and Marx, A.: Anthropogenic warming exacerbates European soil moisture droughts, Nat. Clim. Change, 8, 421-426, https://doi.org/10.1038/s41558-018-0138-5, 2018.

Schaafsma, M. and Bartkowski, B.: Synergies and Trade-Offs Between Ecosystem Services, in: Life on Land, edited by: Leal Filho, W., Azul, A. M., Brandli, L., Özuyar, P. G., and Wall, T., Springer International Publishing, Cham, 1-11, https://doi.org/10.1007/978-3-319-71065-5_117-1, 2020.

Schader, C., Lampkin, N., Muller, A., and Stolze, M.: The role of multi-target policy instruments in agri-environmental policy mixes, J. Environ. Manage., 145, 180-190, https://doi.org/10.1016/j.jenvman.2014.06.016, 2014.

Schlager, E. and Ostrom, E.: Property-rights regimes and natural resources: A conceptual analysis, Land Econ., 68, 249-262, https://doi.org/10.2307/3146375, 1992.

Schröder, J. J., Ten Berge, H. F. M., Bampa, F., Creamer, R. E., Giraldez-Cervera, J. V., Henriksen, C. B., Olesen, J. E., Rutgers, M., Sandén, T., and Spiegel, H.: MultiFunctional Land Use Is Not Self-Evident for European Farmers: A Critical Review, Front. Environ. Sci., 8, 575466, https://doi.org/10.3389/fenvs.2020.575466, 2020.

Schröter-Schlaack, C. and Hansjürgens, B.: Fishing in muddy waters - Governance risks in designing policy responses to manage ecosystem services, in: Atlas of Ecosystem Services: Drivers, Risks, and Societal Responses, edited by: Schröter, M., Bonn, A., Klotz, S., Seppelt, R., and Baessler, C., Springer, Dordrecht; New York, 315-320, 2019.

Seppelt, R., Lautenbach, S., and Volk, M.: Identifying trade-offs between ecosystem services, land use, and biodiversity: a plea for combining scenario analysis and optimization on different spatial scales, Curr. Opin. Environ. Sustain., 5, 458-463, https://doi.org/10.1016/j.cosust.2013.05.002, 2013.

Siebert, L.: Energy Crops and Erosion Control in Germany in the Context of the Bioeconomy Strategy, BonaRes Ser., 2020/2, https://doi.org/10.20387/BonaRes-TZKG-FNRC, 2020.

Soule, M. J., Tegene, A., and Wiebe, K. D.: Land Tenure and the Adoption of Conservation Practices, Am. J. Agric. Econ., 82, 993-1005, 2000. 
Stankovics, P., Tóth, G., and Tóth, Z.: Identifying Gaps between the Legislative Tools of Soil Protection in the EU Member States for a Common European Soil Protection Legislation, Sustainability, 10, 2886, https://doi.org/10.3390/su10082886, 2018.

Techen, A.-K. and Helming, K.: Pressures on soil functions from soil management in Germany. A foresight review, Agron. Sustain. Dev., 37, 64, https://doi.org/10.1007/s13593-017-0473-3, 2017.

Techen, A.-K., Helming, K., Brüggemann, N., Veldkamp, E., Reinhold-Hurek, B., Lorenz, M., Bartke, S., Heinrich, U., Amelung, W., Augustin, K., Boy, J., Corre, M., Duttman, R., Gebbers, R., Gentsch, N., Grosch, R., Guggenberger, G., Kern, J., Kiese, R., Kuhwald, M., Leinweber, P., Schloter, M., Wiesmeier, M., Winkelmann, T., and Vogel, H.-J.: Soil research challenges in response to emerging agricultural soil management practices, Adv. Agron., 161, 179-240, https://doi.org/10.1016/bs.agron.2020.01.002, 2020.

Turpin, N., ten Berge, H., Grignani, C., Guzmán, G., Vanderlinden, K., Steinmann, H.-H., Siebielec, G., Spiegel, A., Perret, E., Ruysschaert, G., Laguna, A., Giráldez, J. V., Werner, M., Raschke, I., Zavattaro, L., Costamagna, C., Schlatter, N., Berthold, H., Sandén, T., and Baumgarten, A.: An assessment of policies affecting Sustainable Soil Management in Europe and selected member states, Land Use Policy, 66, 241-249, https://doi.org/10.1016/j.landusepol.2017.04.001, 2017.

Vainio, A., Tienhaara, A., Haltia, E., Hyvönen, T., Pyysiäinen, J., and Pouta, E.: The legitimacy of result-oriented and actionoriented agri-environmental schemes: A comparison of farmers' and citizens' perceptions, Land Use Policy, 107, 104358, https://doi.org/10.1016/j.landusepol.2019.104358, 2021.
Vogel, H.-J., Bartke, S., Daedlow, K., Helming, K., Kögel-Knabner, I., Lang, B., Rabot, E., Russell, D., Stößel, B., Weller, U., Wiesmeier, M., and Wollschläger, U.: A systemic approach for modeling soil functions, SOIL, 4, 83-92, https://doi.org/10.5194/soil4-83-2018, 2018.

Vogel, H.-J., Eberhardt, E., Franko, U., Lang, B., Ließ, M., Weller, U., Wiesmeier, M., and Wollschläger, U.: Quantitative Evaluation of Soil Functions: Potential and State, Front. Environ. Sci., 7, https://doi.org/10.3389/fenvs.2019.00164, 2019.

Vrebos, D., Bampa, F., Creamer, R. E., Gardi, C., Ghaley, B. B., Jones, A., Rutgers, M., Sandén, T., Staes, J., and Meire, P.: The Impact of Policy Instruments on Soil Multifunctionality in the European Union, Sustainability, 9, 407, https://doi.org/10.3390/su9030407, 2017.

Wiesmeier, M., Mayer, S., Paul, C., Helming, K., Don, A., Franko, U., Steffens, M., and Kögel-Knabner, I.: $\mathrm{CO}_{2}$ certificates for carbon sequestration in soils: methods, management practices and limitations, BonaRes Ser., 2020/3, https://doi.org/10.20387/BONARES-NE0G-CE98, 2020.

Zikeli, S. and Gruber, S.: Reduced Tillage and NoTill in Organic Farming Systems, Germany-Status Quo, Potentials and Challenges, Agriculture, 7, 35, https://doi.org/10.3390/agriculture7040035, 2017.

Zinngrebe, Y., Pe'er, G., Schueler, S., Schmitt, J., Schmidt, J., and Lakner, S.: The EU's ecological focus areas - How experts explain farmers' choices in Germany, Land Use Policy, 65, 93-108, https://doi.org/10.1016/j.landusepol.2017.03.027, 2017.

Zwetsloot, M. J., Leeuwen, J. van, Hemerik, L., Martens, H., Josa, I. S., Broek, M. V. de, Debeljak, M., Rutgers, M., Sandén, T., Wall, D. P., Jones, A., and Creamer, R. E.: Soil multifunctionality: Synergies and trade-offs across European climatic zones and land uses, Eur. J. Soil Sci., 72, 1640-1654, https://doi.org/10.1111/ejss.13051, 2021. 